\title{
NERVE GROWTH FACTOR AND S100B IN BLOOD AND CEREBROSPINAL FLUID AS INDICATORS OF THE SEVERITY OF ISCHEMIC STROKE
}

\author{
L.P. Pivovarova, I.A. Voznyuk, I.V. Osipova, E.A. Gogoleva
}

Saint Petersburg I.I. Dzhanelidze Research Institute of Emergency Medicine, Saint Petersburg, Russia

\section{ФАКТОР РОСТА НЕРВОВ И S100В В КРОВИ И ЛИКВОРЕ КАК ПОКАЗАТЕЛИ ТЯЖЕСТИ ИШЕМИЧЕСКОГО ИНСУЛЬТА}

\author{
Л.П. Пивоварова, И.А. Вознюк, И.В. Осипова, Е.А. Гоголева
}

ГБУ «СПбНИИ скорой помощи им. И.И. Джанелидзе», Санкт-Петербург

ivosipova@yandex.ru

\begin{abstract}
Aim. To determine the relationship between the content of nerve growth factor (NGF) and S100b with the clinical manifestations of acute ischemic stroke (IS). Material and methods. A total of 17 patients with IS, age $68.5(67 ; 78.5)$ years were examined; comparison group: 15 volunteers, age $65.0(62.0 ; 66.5)$ years. The patients' condition was assessed by the size of the brain lesion, the NIHSS and mRS, somatic status. Serum and cerebrospinal fluid (CSF) NGF, S100b, IL6, plasma D-dimer (ELISA) were determined at 1, 3, 10 days after IS. Results. We found NGF decreased in a serum of patients IS with a fatal outcome in $1-10$ days. The dependency of serum $(r=-0.300, p<0.05)$ and CSF $(r=-0.271, p<0.05)$ NGF with the size of the lesion and patients somatic status $(r=-0.322, p<0.05)$ was discovered. The concentration of S100b increased from 3 days in deceased patients in the CSF and blood. The S100b correlated with the outcome of the disease $(r=0.650, p<0.01)$, NIHSS $(r=0.651, p<0.01), \mathrm{mRS}(r=0.451, p<0.05)$. NGF and S100b levels were associated with the increasing of plasma D-dimer and CSF IL-6. Thus the NGF and S100b reflect the brain damage severity and the patients' condition in the acute IS and associates with inflammation activity.
\end{abstract}

Keywords: stroke; NGF; S100b; IL6; D-dimer.

Цель исследования. Определить взаимосвязь содержания ФРН и S100b с клиническими проявлениями ИИ в остром периоде. Материал и методы. Обследовали 17 пациентов с ИИ в возрасте $68,5(67 ; 78,5)$ лет; группа сравнения:15 волонтеров в возрасте $65,0(62,0 ; 66,5)$ лет. Состояние пациентов оценивали по размеру очага поражения мозга, шкалам NIHSS и Рэнкин, соматическому статусу. Определяли содержание ФРН, S100b, ИЛ6 в сыворотке крови и ликворе, Д-димера в сыворотке крови (ИФА) в 1, 3, 10 сутки после ИИ. Результаты. Выявили снижение концентрации ФРН в крови при ИИ с летальным исходом в 1-10 сутки. Отмечена зависимость уровня ФРН в крови $(r=-0,300, p<0,05)$ и ликворе $(r=-0,271, p<0,05)$ от размера очага поражения и соматического статуса пациентов $(r=-0,322, p<0,05)$. Концентрация S100b возрастала с 3 суток у умерших пациентов в ликворе и крови. Отмечены корреляции показателя с исходом заболевания $(r=0,650, p<0,01)$, NIHSS $(r=0,651, p<0,01)$, шкалой Рэнкин $(r=0,451, p<0,05)$. Концентрации ФРН и S100b были связаны с увеличением содержания Д-димера в крови, ИЛ-6 в ликворе. Таким образом, ФРН и S100b отражают тяжесть поражения мозга и состояния пациентов в остром периоде ИИ и ассоциированы с активностью воспаления.

Ключевые слова: инсульт; ФРН; S100b; ИЛ6; Д-димер.

Aim. To determine the relationship between the content of markers of nerve tissue damage nerve growth factor (NGF) and S100b with the clinical manifestations of ischemic stroke (IS).

Material and methods. A total of 17 people with $\mathrm{AI}$ at the age of $68.5(68 ; 75.7)$ were examined; comparison group 15 volunteers aged $65.0(62.0 ; 66.5)$ years. The condition of the patients was assessed by determining at admission somatic status, the size of the lesion of the brain, as well as the severity of stroke according to the NIHSS scale and the degree of disability and functional independence of patients according to the modified Rankin scale (mRS). Blood and cerebrospinal fluid (CSF) for research were taken at 1, 3 and 10 days after IS. Concentrations of NGF, S100b protein, IL6 in serum and CSF; plasma D-dimer were determined by ELISA. Statistical processing of the research results was carried out using STATISTIKA 6.0 software.

Results and discussion. NGF is produced predominantly by glial cells and neurons, is an important factor in protecting nerve tissue cells from apoptosis and necrosis, a modulator of neuromediation in the central nervous system [4]. Reducing the concentration of NGF may be as- 


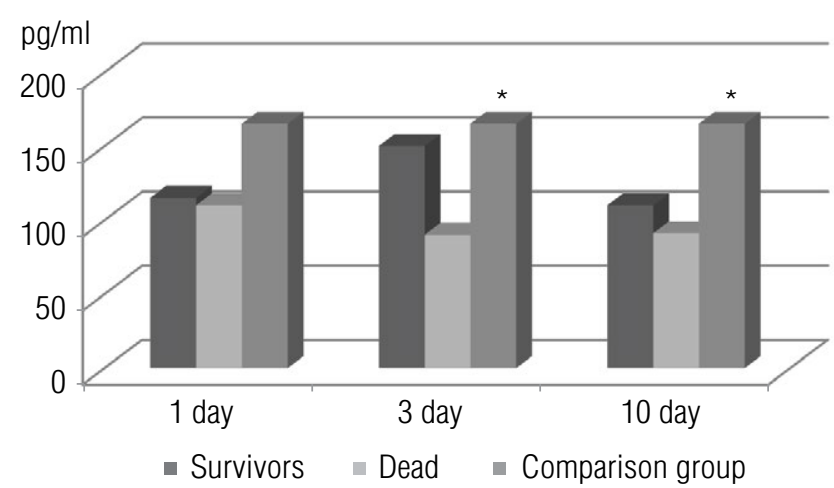

Fig. 1. Serum NGF levels in patients with ischemic stroke. $* p<0.05$ dead-comparison group

sociated with neurological deficit, cognitive and emotional disorders [2, 3, 6]. Protein S100b is a specific protein of astrocytes and Schwann cells, the concentration of which increases in CSF and blood as a result of its increased secretion under the influence of hypoxic or inflammatory stimuli $[1,5]$. The study revealed a decrease in the concentration of NGF in the blood of patients with severe IS and death in 1-10 days after a stroke. NGF concentrations in the blood $(r=-0.300$, $p<0.05)$ and in the CSF $(r=-0.271, p<0.05)$ correlated with the size of the lesion of the brain. A negative correlation dependence of the level of NGF in the blood with the somatic status of pa-

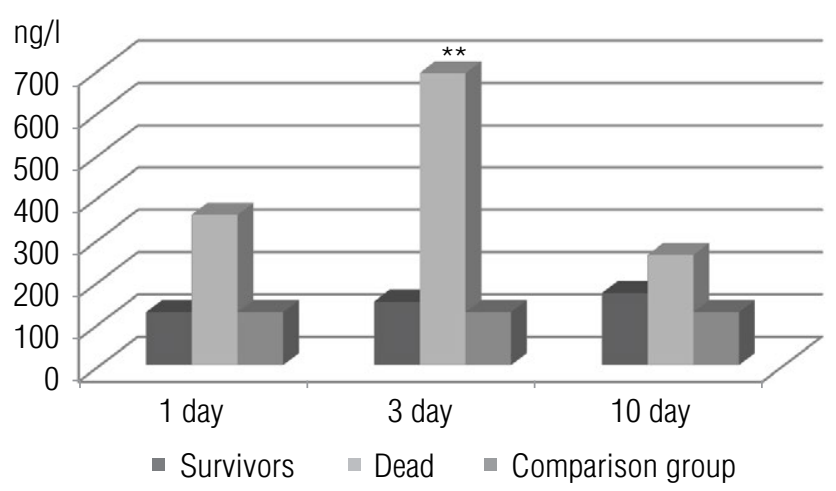

Fig. 2. Serum S100b levels in patients with ischemic stroke. $* * p<0.01$ survivors-dead

tients on admission $(r=-0.322, p<0.05)$ was also detected. The concentration of S100b increased many times from 3 days after IS in the deceased patients in the CSF and to a lesser extent in the blood. The S100b correlated with the outcome of the disease $(r=0.50, p<0.01)$, NIHSS $(r=0.651$, $p<0.01)$ and $\mathrm{mRS}(r=0.451, p<0.05)$. Changes in the concentrations of NGF and S100b were associated with an increase plasma D-dimer and CSF IL6 levels.

Conclusion. The NGF and S100b reflect the brain damage severity and the patients'condition in the acute IS and associates with inflammation activity.

\section{References}

1. Васильев Ю.Г., Берестов Д.С. Гомеостаз и пластичность мозга // Ижевск: ФГБОУ ВПО Ижевская ГСХА. - 2011. $-216 \mathrm{c}$.

2. Гусев Е.И., Скворцова В.И. Ишемия головного мозга. - М.: Медицина, 2001. - 328 с.

3. Каракулова Ю.В., Амирахова Л.Ш. Роль нейротрофинов в восстановлении после ишемического инсульта под влиянием нейропротекторной терапии // Неврологический журнал. - 2014. - № 19(6). C. $31-35$.

4. Фишер М., Шебитц В. Обзор подходов к терапии острого инсульта: прошлое, настоящее и будущее // Журнал неврологии и психиатрии им. С.С. Корсакова. - 2001. - № 2. - С. 21-33.

5. Herrmann M, Vos P, Wunderlich MT, et al. Release of Glial Tissue-Specific Proteins After Acute Stroke. A Comparative Analysis of Serum Concentrations of Protein S-100B and Glial Fibrillary Acidic Protein. Stroke. 2000;31:2670-2677.

6. Luan X, Qiu H, Hong X, et al. High serum nerve growth factor concentrations are associated with good functional outcome at 3 months following acute ischemic stroke. ClinChimActa. 2019 Jan;488:20-24. https:// doi.org/10.1016/j.cca.2018.10.030. Epub 2018 Oct 25. 